\title{
В ПОИСКЕ СВОБОДНОГО ЧЕЛОВЕКА
}

\section{История русско-советской души}

\section{СВЕТЛАНА АЛЕКСИЕВИЧ}

ЛАУРЕАТ НОБЕЛЕВСКОЙ ПРЕМИИ ПО ЛИТЕРАТУРЕ 2015 ГОДА

Лекция Фонда Меюдународных Дел Генри И. Бартельса и Нэнси Хортон Бартельс

12 сентября 2016 года Корнельский Университет 

Я ЛЮБЛЮ ЖИВУЮ ЖИЗНЬ, ту, что на улицах, в человеческом разговоре, крике, плаче. Там она подлинная, не обработанная еще чьейто мыслью и талантом.

Наверное, я научилась этому в детстве. В доме моих родителей, сельских учителей, всегда было полно книг. Но вечером от книг меня тянуло на улицу, где собирались на лавочках деревенские женщины. Время было послевоенное, еще подрывались в лесу мальчишки на немецких и партизанских минах, а в деревнях, как я помню, жили одни женщины. Мужчины не вернулись с войны. Вечером, подоив коров и справившись с домашней работой, женщины сидели на лавочках и говорили о жизни и о смерти-вспоминали войну: как провожали своих любимых на войну, как ждали. Как верили цыганкам, обещавшим им чудо. Их рассказы потрясали больше книг. Жизнь казалась таинственной и страшной.

Долго искала я жанр, который отвечал бы тому, как я вижу мир. Тому, как устроен мой глаз, мое ухо . . . Моя память . . .

И выбрала жанр человеческих голосов . . . В моих книгах обычный, или, как его еще называют, маленький человек сам рассказывает о себе. Я высматриваю, выслушиваю свои книги на улицах, за окном. Иногда могу просидеть целый день с одним человеком. Мне важно словить слово на лету, в рождении. Не упустить разговорную часть жизни, к которой мы относимся невнимательно и небрежно, и она исчезает в суете дней, в темноте времени. То, что это может быть литературой, кажется неожиданным. А я хотела бы все, что есть наша жизнь, сделать литературой. И ежедневное слово тоже.

Более 30 лет я писала свою хронику «красной» империи. Это был невиданный коммунистический проект на огромном пространстве с большим количеством людей-более двухсот миллионов. Русские большевики пытались переделать человека, ветхого Адама, в отдельный человеческий тип-homo soveticus. «Красный» человек, о котором я пишу, это человек советской идеи. Строитель коммунизма, как называл 
он себя. Хроника состоит из пяти книг, и, в тоже время, это как бы одна книга об истории русско-советской души, прослеженной на протяжении почти ста лет. Десятков поколений. Я еще успела застать людей, которые видели Ленина и Сталина, они сидели в сталинских лагерях, но верили в Сталина, дорожили своими партбилетами, красными книжечками с профилями вождей. Помню, как старая коммунистка, отбывшая где-то в далекой Сибири свой срок от звонка до звонка-семнадцать дет, чудом там уцелевшая, для меня так воскресшая из мертвых, грозилась, что напишет донос в КГБ, потому что я клевещу на великого вождя и великое время. Коммунистическая вера была для них религией.

Большую часть жизни я прожила среди этих людей. Этой жизни. Таким был и мой отец, он до конца верил в партию и попросил похоронить партбилет вместе с ним. Последнее, смертельно зараженное коммунизмом поколение. Очарованное утопией.

Даже мы, их дети, их не понимаем. Герои моих последних книг уже были другими . . . Они рассказывали, как воевали в Афганистане, не понимая за что там умирают, рассказывали, как сгребали лопатами расплавленный графит с крыш чернобыльского реактора, делали работу роботов. Как распалась великая «красная» империя, и они остались растерянными в этом новом мире.

Меня интересовал домашний социализм, не героический, помпезный, а тот, который живет в человеческой душе. Я уменьшаю великое до человеческих размеров. Я-историк души. Для меня чувства тоже документ. Занимаюсь пропущенной историей, тем, что история обычно пропускает, история высокомерна и небрежна к маленькому, человеческому. В моих книгах звучит хор и всегда можно расслышать одинокий человеческий голос. Человек для меня существует одновременно в двух мирах—в конкретном времени и в космосе, в вечном. Каждую книгу я пишу 5-7 лет, записываю 500-700 человек- разного возраста, разных профессий, потому что одну войну видела пулеметчица, а другую летчица, которая за всю войну могла не увидеть убитого, она видела только небо. А пулеметчица рассказывала о рукопашном бое, когда человек уже не человек, а зверь, который хочет жить. Режет, колет-в глаза, сердце, живот . . . 
Свои книги я собираю из сотен деталей, оттенков, нюансов. Случалось, что после целого дня разговора оставалась только одна фраза. Но какая! «Я такая маленькая пошла на фронт, что за войну даже подросла». Или вот сижу часа четыре с женщиной, в войну она была автоматчицей и слышу только газетные банальности: «Началась война . . . И мы, советские девочки, вместе с мужчинами рвались на фронт. Так нас воспитала Родина . . .» Уже хочу уйти из этого дома, не надеюсь, что прорвусь сквозь банальности. Пропаганду. Мужской канон. Очень часто моим собеседницам хотелось рассказывать, как мужчина. А я искала детали, запахи, оттенки, которыми женская война отличается от мужской. Ивот уже в прихожей, когда я одеваюсь, женщина просит: «Посиди. Я тебе расскажу . . . Ты никогда не поймешь, как страшно умирать на рассвете. Птицы поют, тишина, а через несколько минут будет команда: «Стрелять!». А трава такая чистая, воздух такой светлый, а надо умирать». Вот тут начинается литература . . . И дальше, уже в конце разговора она вспомнит: «После боя мы ходили по полю и искали живых, вдруг кто-то жив. А они лежат на потоптанной пшенице рассыпанные как картошка, и в небо смотрят-немцы и наши солдаты. Все молодые, хорошие. И тех и других жалко».

Моей целью никогда не было собрать коллекцию ужасов времени, оглушить читателя, я собираю человека. Вопрос Достоевского: «Сколько человека в человеке?» Как этого человека в человеке защитить? Я ищу ответ на этот вопрос. Я собирала человеческий дух. Скажете: эфемерная вещь, неуловимая. Но искусство пытается. У каждого времени свои ответы . . .

Это долгая работа сложить из рассказов образ времени-что за люди жили в то время, как думали, чувствовали? Во что верили, чего боялись? Их суеверия, смутные догадки о смысле жизни . . . У тех, кто воевал, я у всех спрашивала: как человек остается один на один с мыслью, что он имеет право убить другого человека? Убить и не сойти с ума. Слишком просто умирали и слишком просто убивали люди ради великой идеи. Чтобы новое услышать, надо по-новому спросить. Я должна быть интересным человеком. Мне самой тоже надо вырваться из хищных объятий времени, отползти хотя бы немного в сторону. 
У всех моих книг была сложная судьба. Одни долго не печатали, как, например, «У войны не женское лицо», другие даже судили настоящим судом. Судили книгу «Цинковые мальчики». Когда я увидела в зале суда Наташу М., очень удивилась, подошла к ней: «Наташа,—спросила я ее,-а вы что здесь делаете? Вы просили написать всю правду, и я ее написала». Помню маленький гроб ее сына, который еле втиснули в девятиметровую комнату в бараке, она сидела возле него и в безумии то тихо, то громко кричала: «Гроб такой маленький, а ты у меня был большой, под два метра, ты ли там, сынок, ответь маме». Мне она рассказала, как в доме не нашлось никаких дорогих вещей, чтобы откупить сына от войны. «Я бы все отдала, я бы его выкупила, как другие, но у меня даже золотых сережек не было. Напиши,-пплакала она,- сын был столяр. Его призвали в армию, и с первого дня он не на учения ходил, а генералам дачи ремонтировал. Его даже стрелять не научили. Убили в первый же месяц».-«Что же, Наташа, ты здесь делаешь?-не могла поверить я.-«Мне нужен сын герой, а ты написала, что он убийца. Как они убивали . . .» Что я могла ей ответить, если даже страдание не сделало ее свободной. Мы были не просто рабы, а романтики рабства.

Книгу «У войны не женское лицо» три года не печатали, обвинив меня в натурализме, пацифизме. Цензора особенно возмущал эпизод, рассказывающий, как идет 200 военных девчонок, а за ними идут мужчины, и мужчины стараются не смотреть вниз, на песке остаются кровавые следы. У женщин есть особые дни, им нужна была вата или еще что-нибудь, а это в советской армии не давали. Женщинам стыдно. Когда они доходят до переправы, их начинают бомбить. Мужчины прячутся, а женщины все в воду, чтобы помыться-отличная мишень! Почти всех их расстреливают с воздуха. «Что вы в биологию лезете! Надо героизм описывать!»-кричал цензор. Пыталась ему доказать, что человек-он всякий, он из всего и из биологии тоже. Тело меня интересует как связь между природой и историей. Идеалы не могут быть гипсовыми как памятники. Все-таки из первого издания эту страницу вычеркнули. Я смогла ее восстановить только через 10 лет. В годы перестройки. Цензор даже такой абзац выбросил: я спрашивала женщину, бывшую снайпером: «Что вы взяли с собой на войну?-Ответ: «Чемодан конфет. На всю последнюю зарплату купила шоколадных конфет». И мы хохочем. «Разве 
это история? Эти конфеты . . .»-был разозлен цензор. «История,ответила я.-Такие детали потрясают больше всего».

Иногда меня упрекают, что в моих книгах люди слишком красиво говорят. В любви и возле смерти человек всегда говорит красиво, в эти моменты он выше себя обычного, поднимается на цыпочки. Вот такого человека я сторожу. Выглядываю в жизни. Человека, потрясенного жизнью. Бытием. Рассказывая, человек творит, он не копирует реальность, а творит. Воспоминания-живые существа. В свои воспоминания люди складывают всю свою жизнь: что читали, о чем думали, счастливы или нет. Документы движутся вместе с человеческой душой, наивно думать, что это некое каноническое знание, которое недвижимо и механически передается из одного время в другое. После перестройки многие мои герои добавили целые страницы в свои рассказы, они стали свободнее и глубже заглянули в самих себя. Глубже и отважнее. Я получала письма: «Тогда я боялась ... Вы же знаете, как опасно было говорить о Сталине. Даже о войне нельзя было сказать всю правду. А теперь решила написать ... .»

С годами я тоже изменилась, я тоже больше знаю и догадываюсь о человеке. Знаю, чувства не простая, прямолинейная, голая вещь. Документ может обо всем рассказать, все поднять. Меня всегда мучило, что правда не вмещается в одно сердце, в один ум. Что она такая раздробленная, ее много и она рассыпана в мире. Не соглашаюсь, когда мне говорили, что документ не может рассказывать о личном, сокровенном. Об этом трудно написать, но можно написать. Кто поверит человеку без этого . . . без сердца . . .

Мои герои часто признавались мне: вам расскажу, потому что только советский человек может понять советского человека. Мол, другие нас не понимают. Русская душа загадка. А мы жили в стране, где нас с детства учили умирать. Учили смерти. Нас не учили, что человек рождается для счастья, для любви, нам твердили, что человек существует, чтобы отдать себя, чтобы сгореть, чтобы пожертвовать собой. Учили любить человека с ружьем.

Мой путь растянулся на десятки лет. Не всегда он был мне под силу. Я восхищалась человеком и пугалась его. Если бы я родилась в другой 
стране, то я бы не смогла пройти этот путь. Зло беспощадно, к нему нужно иметь прививку. Но мы выросли среди палачей и жертв. Пусть наши родители жили в страхе и не все нам рассказывали, а чаще ничего не рассказывали, но сам воздух нашей жизни был отравлен. Зло все время подглядывало за нами.

Первая моя книга «У войны не женское лицо»-о войне, увиденной и рассказанной женщиной. Почему о войне? Потому что война всегда в центре нашей жизни. Мы-военные люди. Мы или воевали или готовились к войне. Все, что мы знаем о войне, мы знаем с «мужского голоса». Мы все в плену «мужских» представлений и «мужских» ощущений войны. «Мужских» слов. Рассказывая, женщины всегда подстраиваются под «мужской» канон, рассказывают не «женскую», а «мужскую» войну. В своих журналистских поездках я часто встречалась с военными женщинами. Если удавалось их вырвать из банальности, в их рассказах проглядывал чудовищный оскал таинственного . . . новый текст . . . Когда женщины говорили, у них не было или почти не было того, к чему мы привыкли, как одни люди героически убивали других и победили. Или проиграли. Какая была техника и какие генералы. Женские рассказы другие и о другом. Там свои краски, пространство и освещение. Свои слова. Там нет героев и казенных подвигов, там есть просто люди, которые заняты человеческим нечеловеческим делом. И страдает все живое, а не только люди: птицы, деревья . . . Страдают они без слов, что еще страшнее. Мне открывался грандиозный и хищный мир войны.

Как одновременно переживать историю и писать о ней? И нельзя любой кусок жизни, всю экзистенциальную «грязь» взять за шиворот и втащить в книгу. В историю. Надо «проломить» время и «уловить дух».

Если мужчина заложник культуры войны, то женщина свободна. В женских рассказах все равно присутствует мысль, что война-это убийство. Все равно убийство.

Тексты я находила всюду. В городских квартирах и деревенских избах, на улице, в поезде. Я училась слушать, все больше превращаясь в одно большое ухо.

После первой книги «У войны не женское лицо» я решила идти за временем. Идти за человеком: как он меняется, что с ним происходит? С ним, а значит с нами. Рассказ одного человека-это его судьба, а рассказ сотни людей-история. 
Книга «Цинковые мальчики» началась с маленькой девочки. Я не могла забыть ее. На городском кладбище в Минске хоронили офицеров, которых привезли в цинковых гробах из Афганистана. Воинственные речи, венки . . . А маленькая девочка, как птичка, вырывалась из рук взрослых и кричала: «Папа! Папа! Я тебе нарисовала много корабликов, как ты просил. Где ты?»

Я поняла, что я поеду . . . я должна поехать в Афганистан . . . Хотя до этого мне казалось, что я не смогу больше писать о войне. По телевизору показывали, как наши военные сажают деревья в Афганистане, строят дома . . Говорили об интернациональном долге, державных интересах.

И вот я сама на войне . . .

Первый раз, проезжая по улочкам Кабула, увидела знакомые плакаты «Светлое будущее-коммунизм», «Кабул-город мира», «Народ и партия едины». Ощущения, что я в Минске, а не в Кабуле.

И вот я первый раз сама вижу убитого человека. Убитого не молнией, не стихией, а другим человеком.

Я увидела, как установка «Град» превращает глиняные кишлаки в перепаханное поле. Была на бесконечном афганском кладбище, где кричала, как раненый зверь, старая афганка. Я вспомнила, как в деревне под Минском внесли в дом цинковый гроб, и точно так же выла мать. Это не человеческий крик был и не звериный . . .

Первая мысль: как найти слова? Кто мне дал надежду? Надежду дал свидетель. Только его слова были равны тому, что я увидела и о чем хотела рассказать. Сегодня для меня свидетель-главный герой литературы. Мне говорят: ну, воспоминания-это не история и не литература. Это просто жизнь, замусоренная и не очищенная рукой художника. Сырой материал говорения. Но для меня все иначе . . . Именно там, в живом человеческом голосе, в живом отражении реальности скрыта тайна нашего присутствия здесь, обнажен неустранимый трагизм жизни. Ее хаос и страсть. Единственность и непостижимость. Плач и крик нельзя подвергать обработке, иначе главным будет не плач и крик, а обработка.

Я строю храмы из наших чувств . . . наших желаний и разочарований. Мечтаний. Из того, что было, не может ускользнуть.

До Афганистана я верила, что мы построим социализм с человеческим лицом. Так учил меня отец. Из Афганистана я вернулась свободной от 
всех иллюзий. «Прости меня, отец,-сказала я вернувшись с войны,ты воспитывал меня с верой в коммунистические идеалы, но достаточно один раз увидеть, как убивают наши солдаты, на чужой земле убивают неизвестных им людей, чтобы все эти идеалы превратились в прах». Отец заплакал.

Жизнь немыслимо художественна сама по себе, и как это ни жестоко звучит-особенно художественно человеческое страдание. В этом темная сторона искусства. Я всегда занимаюсь тем материалом, который подводит к границе невозможного. Ты остаешься один на один с реальностью.

Книгу о Чернобыле я писала 10 лет. После нее я могу сказать, что не пишу, а проживаю свои книги.

Чернобыль был прыжком в новую реальность. Произошедшее превосходило не только наше знание, но и наше воображение. Bce, с кем я говорила, постоянно повторяли: «Я нигде об этом не читал», «Я никогда это ни в одном кино не видел», «Никто ничего подобного мне не рассказывал». Все было как прежде, но мир совершенно изменился. Накопленные нами знания об ужасах связаны с войной. А в Чернобыле цвели деревья, все росло, летали птицы, но люди чувствовали, что во всем присутствует смерть. Невидимая, неслышная. Смерть в новом обличии. Прошлое было бессильно нам в чем-либо помочь.

Я поехала в чернобыльскую зону. То, что я там увидела, заставляло молчать. У всех были растерянные, почти сумасшедшие лица. Смотрели, как срезают верхний зараженный слой земли и хоронят в специальных ямах. Землю хоронили в земле. Солдаты мыли дороги, дома, деревья, дрова . . . И хоронили, хоронили. Хоронили вещи, яйца, молоко, хоронили расстрелянных зараженных животных. Чернобыльская информация в газетах была сплошь из военных слов: взрыв, герои, солдаты, эвакуация . . . По направлению к Чернобылю двигалась военная техника, в кузовах машин сидели солдаты с автоматами. Система действовала, как обычно в экстремальных условиях-много техники, много солдат, но солдат с автоматом в этом новом мире был трагичен. Все, что он мог-набрать большие радиодозы и умереть, когда вернется домой. К военному атому люди были готовы, к мирному нет, они еще не знали, что военный и мирный атом-сообщники, они одинаково убивают. 
Помню, как эвакуировали одну деревню: люди садились в автобусы, а собаки и кошки бегали вокруг, их оставляли. Человек спасал только самого себя. Возле старого дома стояла старая женщина с иконой и не хотела садиться в автобус. Увидев меня, она подошла и спросила: «Я видела войну, а тут солнце светит, даже мышку сегодня видела, почему я должна бросить свою хатку? Разве это война?» «Да, это война. Наверное, так и будут начинаться войны будущего,-—подумала я.-Да, это война. Это другая война, нам неизвестная».

Старый пасечник рассказывал, как пчелы неделю не вылетали из улья, а рыбаки вспоминали, что не могли выкопать ни одного червяка, они ушли глубоко в землю. Пчелы, червяки, жуки что-то знали, чего еще не знал человек.

Я поняла, что у меня нет инструмента, подхода к этой теме. Событие еще вне культуры. В те дни я услышала: «Мы беларусы-черные ящики, которые записывают информацию для будущего».

Повсюду звучали совершенно незнакомые тексты.

Вот, например, рассказ жены пожарника, тушившего пожар на крыше реактора в первую ночь: «Тебе нельзя подходить к своему мужу, нельзя его гладить, целовать. У него острая лучевая болезнь.-Не пускали ее врачи к мужу.-Пойми, это уже не любимый человек, а объект, подлежащий дезактивации». Радиацию нельзя было увидеть-глаза не годились, у нее не было запаха, к ней нельзя было дотронуться, нельзя было услышать-уши, нос, пальцы-ничего не годилось. Нужны были новые слова, их тоже не было.

Недалеко от реактора я увидела деревенских мальчишек на велосипедах, они приехали вечером посмотреть на пожар, на малиновое сияние, исходящее от дымящего реактора. Небо действительно было красивое. Красота и смерть были рядом. Но мы еще об этом не знали.

Церкви были полны людей, но единственное, что они там находилиэто утешение. Но чтобы выжить, надо было понять. Как оказывать сопротивление тому, чего не знаешь? Люди становились философами, потому что перед лицом этой мистерии каждый был представлен самому себе. Чернобыль каждого из нас осудил на бесконечное одиночество. Зло приняло такие размеры, что мы вышли за свои пределы, но все равно не могли его понять. Сознание капитулировало, наука капитулировала. А подсознание начало работать. Люди боялись 
неких монстров, рассказывали о детях с пятью головами, о птицах без головы и без крыльев . . . Пугали друг друга фантазиями: в секретных местах закапывают тысячи трупов . . .

Беларусь-аграрная страна, архаическая. Крестьяне живут в тесной связи с природой. До сих пор еще на своих усадьбах используют простые орудия-топор, лопату, плуг. Что я открыла для себя? Если ученые, политики, военные были растеряны, то у деревенских старых людей картина мира не нарушилась. Не знаю, что им помогало. Может смирение перед тем, что они могут исчезнуть вместе с природой. «Вот ничего, что с нами происходит, нет ни у Чехова, ни у Толстого»сказала мне одна учительница. Все сами искали новые ориентиры в этом новом мире. Официальная пропаганда, культура, философия были парализованы. Хранили молчание. Если бы мы осмыслили Чернобыль, то о нем было бы написано намного больше. Знание о нашем незнании мешает нам. Чернобыль изменил наше понятие временимногие радиочастицы будут жить сто, двести, тысячу лет, изменив пространство-через несколько суток радиоактивные тучи были уже над Африкой. Перечеркнуты такие понятия, как «свои» и «чужие». Для радиации не существует границ.

Одним словом человек был потрясен, и я торопилась-услышать, записать.

У меня не было ощущения, что я записываю прошлое, я записывала будущее. И постоянное чувство, рассказывая о катастрофе, не можешь не думать о катастрофе рассказа. А все-таки, как найти язык?

У нас много языков-на одном языке мы говорим сами с собой, на другом с детьми, на третьем с любимыми, а еще есть язык, на котором мы говорим с животными . . . С Богом . . . Язык разговорной речи не обременен, выпущен на волю. Все гуляет и празднует: синтаксис, интонация, акценты, и восстанавливается в точности чувство. Я слежу за чувствами, я историк бесследного.

В Афганистане солдат рассказывал, как азартно убивать вместе. И как неприятно расстреливать, особенно если увидел глаза человека.

В Чернобыле дети подходили и спрашивали: «Тетя, ты писатель, ты должна знать, а будут ли в будущем году у деревьев листочки? Появятся ли у рыб мальки?» 
Я слышала, как плакала молодая мама, у которой родилась больная девочка и прожила всего год: «У нее было только три пальчика на каждой руке. Я клала ее тельце в гробик и думала: «Хоть бы у нее пальчики были все, она же девочка».

Разве это останется в истории? История отвернется, а я потрясена.

Если бы я не читала Достоевского, я была бы в отчаянии перед человеческой душой, перед ее бесконечностью.

Афганистан и Чернобыль похоронили империю. Мы простились c той нашей жизнью, которая называлась социализм. Мой цикл заканчивался. В заключительной книге цикла «Время сэконд-хэнд» я попыталась честно выслушать всех участников коммунистической драмы. Героев не надо было искать, были мы все. Империя пала, а мы остались. Все мы, люди из социализма, похожи и не похожи на остальных людей, у нас свои представления о добре и зле, о героях и мучениках. У нас свои отношения со смертью, в рассказах постоянно звучат слова: «расстрелять», «ликвидировать», «пустить в расход», «десять лет без права переписки» (что означало исчезновение, арест). Все полны ненависти и предрассудков. Жили в лагере. Если человек вышел за ворота лагеря, это не значит, что назавтра он свободный человек. Все, что он знает-это лагерь, цена человеческой жизни тоже оттуда, из лагеря. Писатель Варлам Шаламов, оставивший незыблемые документы о лагере, просидел он почти 20 лет-писал: «Лагерный опыт развращает и палача и жертву».

В 90-ые годы открыли архивы, и перед нами встали вечные русские вопросы: что делать и кто виноват? Сталин? Берия? На мой взгляд, коренная наша проблема-проблема добра и зла. В книге «Время сэкондхэнд» есть такая история: один из героев рассказывает, как мальчишкой был влюблен в тетю Олю-красивый голос, красивые волосы. Потом, когда он учился уже в университете, началась перестройка, и мама ему призналась, что ее сестра, тетя Оля, в годы сталинских репрессий донесла на собственного брата, и он сгинул где-то на Колыме. Когда он приехал домой на каникулы, он спросил у тети Оли, что она может вспомнить о 37-ом годе, когда арестовали брата. «О! Это было прекрасное время,-—ответила тетя Оля,-меня любили, и я любила». Юноша задал ей еще один вопрос: «А как же брат?»-«Попробовал бы 
ты найти в сталинское время честного человека. Время было такое»услышал он в ответ. Я о том, что нет химически чистого зла. Зло это и Сталин, и красивая тетя Оля.

Правда была страшной, опасной. Мы испугались своего прошлого, и архивы быстро закрыли. Как стояли, так и стоят везде коммунистические памятники, везде гипсовый Ленин стоит, тело лежит в мавзолеепирамида Хеопса, построенная в XX веке. Не судили компартию, не было люстрации. Прошлое не отпустило, мы все им нашпигованы.

То, что я делаю, я не хочу называть интервью-это разговор о жизни. Я прихожу к другому человеку, как к другу. Мы разговариваем обо всем: и о новой кофточке, и о любви, и о войне. В этом разговоре не должно быть никакой искусственности, никакого барьера. Мы просто разговариваем. О добре и зле, о социализме и капитализме, о свободе . . . Слышала сотни ответов. Все они это и есть мы, какие мы сейчас. На вопрос: какой должна быть страна-сильной или достойной, где людям хорошо жить, восемь человек из десяти выбирали-сильной. В перестройку мы были романтиками, мы думали, что свобода будет завтра. Была у нас такая наивная уверенность. Сегодня мы знаем, что свобода-это долгий путь. На этом пути нас ждет много опасностей и искушений. У нас нет опыта свободы, у нас только лагерный опыт.

На книжных развалах лежат сотни книг, все напечатали: Солженицына, Шаламова, Гинзбург . . . За эти книги когда-то сажали в тюрьму, выгоняли из университетов. Теперь люди пробегают мимо. Захлестнуло материальное: купить новую кофемолку, стиральную машину, в магазинах десятки сортов колбасы и сыра-все попробовать. Предел мечтаний-старая машина из Европы, шенгенская виза и поездка в Турцию, Египет. Уже никто не стоит всю ночь в очереди за книгой. Все мы были больны, несчастны. Людям хочется жить, просто жить, узнать радость от красивой вещи, одежды.

Опыт развала «красной» империи уникален. Крутой поворот от социализма к капитализму потряс людей, они не были к этому готовы. Такой поворот случился впервые в истории. Страна разделилась: одни вспоминают время перестройки как великое время. Я помню, как сразу поменялись лица людей, даже пластика движений. Пьянил воздух свободы. Мое поколение счастливо: оно хотело разрушить коммунизм, и оно его разрушило. Другие считают, что это была геополитическая 
катастрофа. Я вспоминаю, как хорошо сидели мы на кухнях, мечтали о свободной стране, а когда нас выбросило из замкнутого круга в мир, в общую реальность, испугались. Свобода представлялась праздником, ходили по улицам и площадям, скандировали: «Свобода! Свобода!», но понятия не имели, что это такое-свобода. Я спрашивала у своих героев: «Как вы представляли себе свободу в 90-ые годы?»-«Мы думали, что у нас будут такие же магазины, как на Западе. Будет полно всего». Никто не представлял свободу как работу. Когда поняли, все растерялись. И интеллектуалы, и политики. Не представляли, что свобода потребует свободных людей, какими мы не были. Мы не впустили в себя мир, закрылись от него. Теперь всех пугаем, что русские хорошие солдаты, за ценой не постоят, жизнь у нас дешевая. Знаем один способ, как заставить нас уважать-нас должны бояться.

Пришел Путин—и мир нас боится.

Я не политик и не экономист, я художник. Весь этот хаос мне надо было организовать, нащупать силовые линии. Сделать это искусством. Дать каждому прокричать свою правду, чтобы понять кто мы. В книге говорят палачи и жертвы, молодые и старые. На пересечении версий рождается ответ. И вопросы, вопросы . . К Каким образом так быстро Путин восстановил сталинскую машину? Опять ФСБ (бывшее КГБ) может ворваться в любой дом, конфисковать компьютер, засудить блогера за пост в поддержку Украины, по всей стране ищут и судят якобы шпионов-ученых, учителей, военных. Люди запуганы, и что на самом деле происходит в обществе, что оно думает-неизвестно. Непонятно. На один вопрос я так и не нашла ответ: почему наши страдания не конвертируются в свободу.

Я иду вслед за временем. За человеком. 


\section{О СВЕТЛАНЕ АЛЕКСИЕВИЧ}

Светлана Алексиевич родилась в Украине в 1948 году; выросла и получила образование в Беларуси. Она училась ана юурналиста, но со временем стала писателем. При творческой поддержке Беларусского писателя Алеся Адамовича, Светлана Алексиевич создала свой собственный жанр, который она определяет как хор отдельных голосов и коллаж деталей повседневности. Сбор материала и процесс написания книг, по ее словам, позволяют ей быть одновременно и писателем, и репортером, и социологом, и психологом, и проповедником.

Пять документальных книг Алексиевич были опубликованы в более чем патидесяти странах и переведены на более сорока языков. Ее перу также принадлеюат три пьесы и сценарии более чем двадцати документальных фильмов. Ее творчество принесло ей много различных премий, а в 2015 году ей была присуждена Нобелевская премия по Литературе. Согласно формулировке Нобелевского комитета, ее “полифоническое письмо является памятником страданию и мужеству современной эпохи”. 


\section{О ПОЧЕТНОЙ СТИПЕНДИИ (СЕМЬИ) БАРТЕЛЬС}

Почетная стипендия Генри И. Бартольса и Нэнси Хортон Бартельс была основана в 1984 году с целью обеспечить возможность приглашения выдающихся деятелей международной политики для выступления в Корнельском университете в городе Итака, штат Нью-Йорк. В дополнение к публичной лекции, открытой для университетского сообщества и широкой публики, лауреаты этой стипендии, проводят два или три дня в университетском кампусе, встречаясь и общаясь с преподавателями и студентами.

Присуждение Бартельсовских стипендий и связанные с ней процедурные вопросы находятся в ведении Центра Международных Исследований Марио Эинауди.

\section{О ЦЕНТРЕ ЭИНАУДИ}

Центр Международных Исследований Марио Эинауди был основан в 1961 году с целью поддержки исследования, изучения и преподавания в Корнеле тем, связанных с различными регионами и странами мира, их культуры и языков. В 1999 году Центру было присвоено имя его основателя и первого директора, ученого-политолога Марио Эинауди. На сегодняшний день, Центр является домом международных исследований и тематических программ, организует серии выступлений приглашенных докладчиков, конференции и другие мероприятия, распределяет денежные гранты и стипендии для преподавателей и студентов, и организует встречи ученых, работающих в различных областях исследований, для обсуждения сложных вопросов, касающихся международных проблем. 